\title{
“THE RUSSIAN WORLD” ON THE BUDVA RIVIERA: TOURISM AND FOREIGN POLICY PROCESS IN THE MONTENEGRO
}

\author{
«РУССКІЙ МІР» НА БУДВАНСЬКІЙ РИВ'ЄРІ: ТУРИЗМ І \\ ЗОВНІШНЬОПОЛІТИЧНИЙ ПРОЦЕС У ЧОРНОГОРЇ̈
}

\author{
«РУССКИЙ МИР» НА БУДВАНСКОЙ РИВЬЕРЕ: ТУРИЗМ И \\ ВНЕШНЕПОЛИТИЧЕСКИЙ ПРОЦЕСС В ЧЕРНОГОРИИ
}

\author{
Parfinenko A.
}

Ph.D (History), Assoc. Prof., Head of the Department of Travel Business and Regional Studies of the V. N. Karazin Kharkiv National University. E-mail: parfinenko@karazin.ua

\section{Парфіненко А.}

Кандидат історичних наук, доцент, завідувач кафедри туристичного бізнесу та країнознавства Харківського національного університету імені В. Н. Каразіна. E-mail: parfinenko@karazin.ua

\section{Парфиненко А.}

Кандидат исторических наук, доцент, заведующий кафедрой туристического бизнеса и страноведения Харьковского национального университета имени В. Н. Каразина. E-mail: parfinenko@karazin.ua

Abstract. The article is devoted to the study of the role and place of tourism in the transformation of the foreign policy course of post-Yugoslavian Montenegro. The focus is on the impact of Russian tourism on key directions and foreign policy problems of the country. The work is based on the concept of transnationalism. Within this approach, global tourist flows are considered as a kind of transnational social space, in which the tourist is always an actor, performing various social actions related to interaction with the different environment.

The publication reveals a historical retrospective of geopolitical presence of Russia in the Western Balkans. The cultural, investment and tourism components of Russia's influence on the social and political life of post-Yugoslavian Montenegro are highlighted. Principal indicators of tourism development in the country, the contribution of Russian tourism to the total volume of international tourist arrivals are investigated. Significant politicization of the tourist process in Montenegro is claimed. In mono-dependent on international tourism economy of Montenegro, tourism has influenced the politically-motivated rethinking of the traditions of relations with Serbia, Russia and the West. It has become a factor in the electoral struggle in the society and affected the transformation of Montenegro's geopolitical landmarks. The publication analyzes Russia's attempts to destabilize the country's political situation in the context of its accession to NATO. First of all, by exploiting Montenegro's dependence on Russian investment and tourist flows, the application of information warfare technologies.

Culture and tourism are said to be an important component of the new concept of sovereignty, where demonstration of openness and a new European identity have underpinned Montenegro's geopolitical transformation - from the Balkans to the country that has come close to the EU. At the same time, Montenegro's example reflects the increasing political and economic importance of tourism in the world political processes and ensuring international political interaction.

Key words: Montenegro, Yugoslavia, Western Balkans, International Tourism, Tourist Flows, Foreign Policy, Geopolitics, European Integration.

Анотація. Статтю присвячено вивченню ролі та місия туризму у трансформаціі зовнішньополітичного курсу постюгославської Чорногорії. В чентрі уваги - вплив 
російського туризму на ключові напрямки та проблеми зовнішньої політики країни. Робота спирається на кониепиію транснаціоналізму. В межах даного підходу глобальні туристичні потоки розглядаються як своєрідний транснаціональний соціальний простір, у якому турист завжди є актором, оскільки виконує множину сочіальних дій, пов'язаних із взаємодією з іншим середовищем.

Публікація розкриває історичну ретроспективу геополітичної присутності Росії в регіоні Західних Балкан. Висвітлено культурну, інвестиційну та туристичну складові впливу Росії на суспільно-політичне життя постюгославської Чорногорії. Досліджено основі показники розвитку туризму в краӥні, внесок російського туризму у загальний обсяг міжнародних туристичних прибуттів. Стверджується про значну політизацію туристичного процесу в країні. У монозалежній від міжнародного туризму економіці Чорногорії туризм вплинув на політично-мотивоване переосмислення традицій відносин $з$ Сербією, Росією та Заходом. Він став чинником електоральної боротьби в суспільстві та позначився на трансформації геополітичних орієнтирів держави. $B$ публікації проаналізовано спроби Росії з дестабілізації політичної ситуації в країні у контексті ї вступу до НАТО. Передусім, иляхом експлуатаиії залежності Чорногорії від російських інвестицій та туристичних потоків, застосовування технологій інформаційної війни.

Стверджується, щуо культура та туризм виступили важливою складовою нової концепиії суверенітету, де демонстрація відкритості та нової європейської ідентичності виступили основою геополітичної трансформачії Чорногорї - від Балкан до крайни, яка впритул наблизилася до ЄС. Водночас, приклад Чорногорії відображає чимраз зростаючу політико-економічну вагу туризму у світових політичних процесах та забезпеченні міжнародно-політичної взаємодіі.

Ключові слова: Чорногорія, Югославія, Західні Балкани, міжнародний туризм, туристичні потоки, зовнішня політика, геополітика, європейська інтеграція.

Аннотация. Статья посвящена изучению роли и места туризма в трансформации внешнеполитического курса постюгославской Черногории. В иентре внимания - влияние российского туризма на ключевые направления и проблемы внешней политики страны. Работа опирается на кониепџию транснационализма. В рамках данного подхода глобальные туристические потоки рассматриваются как своеобразное транснациональное сочиальное пространство, в котором турист всегда является актером, поскольку выполняет множество социиальных действий, связанных $c$ взаимодействием с другой средой.

Публикаиия раскрывает историческую ретроспективу геополитической присутствия России в регионе Западных Балкан. Освещены культурная, инвестиционная и туристическая составляющие влияния России на общественно-политическую жизнь постюгославской Черногории. Исследованы основные показатели развития туризма в стране, вклад российского туризма в общий объем международных туристических прибытий. Утверждается о значительной политизачии туристического процесса в стране. В монозависимой от международного туризма экономике Черногории туризм повлиял на политико-мотивированное переосмысление традиций отношений с Сербией, Россией и Западом. Он стал фактором электоральной борьбы в обществе и сказался на трансформации геополитических ориентиров государства. B публикации проанализированы попытки России по дестабилизации политической ситуации в стране в контексте ее вступления в НАТО. Прежде всего, путем эксплуатации зависимости Черногории от российских инвестиций и туристических потоков, применения технологий информационной войны.

Утверждается, что культура и туризм выступили важной составляющей новой концеепции суверенитета, где демонстрация открытости и новой европейской идентичности выступили основой геополитической трансформации Черногории - от Балкан до страны, которая вплотную приблизилась к ЕС. В то же время, пример 
Черногории отражает все более возрастающий политико-экономический вес туризма в мировых политических процессах и обеспечении международно-политического взаимодействия.

Ключевые слова: Черногория, Югославия, Западные Балканы, международный туризм, туристические потоки, внешняя политика, геополитика, европейская интеграиия.

Research problem setting. Contemporary international tourism is a complex, transnational entity that is developing globally, and is deeply integrated into global economic and trade relations. The structure of global tourism flows has not only its economic logic but also its political tradition, political connections and deep-rooted political implications. Mass travel practices that, through the proliferation of modern means of communication, are actively expanding their network, form a kind of transnational social space, in which the tourist is always an actor, because they perform a variety of social actions related to interaction with a different environment.

The foregoing can be fully applied to such a small Balkan country as Montenegro, with a population of about 625,000. The Budva Riviera occupies the central part of its coast and is the most attractive tourist wherebeautiful beaches, bays and gulfs of such localitiesas Budva, Sveti Stefan, Petrovac, Becici, Rafailovichi, Przno and etc. blend harmoniously into the 38-kilometer coast. This is one of the sunniest places in the Adriatic, which has become widely known in the world tourist markets and is used in the title of the proposed publication as a symbol of Montenegro tourismt mono-dependence. The aggregate contribution of tourism and travel to Montenegro's GDP is about 22\% [WTTC, 2019], which is one of the highest indicators in Europe, along with Malta and Croatia. Moreover, this applies not only to the economy but also to politics, since Russia is one of the main tourist-generating flows for the country, for which the resort "capital" - Budva - is sometimes called "Moscow at Sea". Tourism and related investment flows have become one of the major factors in the Kremlin's foreign policy influence to destabilize the region and prevent Montenegro from joining the NATO. Considering this, the study of the international political impact of tourism in such mono-profile countries as Montenegro deserves full attention.

For Ukraine, the relevance of Montenegro's foreign policy research is also related to both a similar communist past within the Allied states and features of democratic transit, a commonality of foreign policy strategies based on European and Euro-Atlantic integration, identical challenges caused by Russia's attempts to resume political influence through the exploitation of Orthodox faith, Pan-Slavic identity and economy.

The objective of the article. The purpose of the proposed study is to define the role and place of tourism in the transformation of the foreign policy of post-Yugoslavian Montenegro, including the impact of Russian tourism on key directions and problems of the country's foreign policy. The focus is on the analysis of international political processes that have determined the increase in tourism in the region and the impact of transnational tourism flows on economic, cultural and foreign policy processes in the host country.

Analysis of recent research and publications. As a rule, international political processes in Montenegro are considered in the context of the foreign policy of former Yugoslavia, the Balkan wars of the 1990s, the post-communist transformations in the countries of Europe, against the background of other processes, and comprises thousands of publications. In fact, Montenegro's foreign policy coverage is represented by a relatively limited body of scientific research, which is explained by the country's recent independence (2006). Among the relevant works it is worth noting the publications by K. Boeckh [Boeckh, 2014], B. Vukićević [Vukićević,2017], J. Džankić [Džankić, 2014], G. Djurovic [Djurovic, 2012] and others, which consider the adaptability of the country to changes in the global and regional geopolitical environment, relations with allies, European integration policy, foreign and security policy priorities. Montenegro-Ukrainian relations are considered against a broad background of political, economic and cultural processes in a monograph by O. Slyusarenko [Slyusarenko, 2012] and a publication by M. Frolov [Frolov, 2016]. With regard to tourism, its impact on socio-economic processes in the republics of former 
Yugoslavia is partly reflected in the collective publication, edited by Grandits H. and Taylor K. [Grandits, Taylor, 2010]. Within the scope of the proposed publication, special attention is paid to the section of a monograph by A. Violante [Violante, 2017], devoted to revealing the relationship between Russia's financing of tourism projects in Montenegro and the achievement of relevant geopolitical influences. Nevertheless, rapid dynamics of socio-political processes in the country, triggered by the accession to NATO and EU membership prospects, led to a significant politicization of the tourism process in the country, necessitating the need for further study of the international political impact of tourism in Montenegro's foreign policy development.

Outline of the base material. The always tense geopolitical situation in the region has branded it the status of a troubled one, which is associated not with tourism and travel but with war and conflict. The development of mass tourism on the Adriatic coast of Montenegro dates back to the 1960s, and also depends on the foreign policy pursued by Yugoslavia. However, to understand the general context of Russia's cultural and political presence in this small country, first, we propose to consider the main stages of their interaction concisely.

Russia has never concealed its geopolitical interests in the Balkans, identifying them as the sphere of its strategic priorities. Along with the traditional guardianship of the Orthodox Slavic peoples, this interest had a very practical political level associated with rivalry with Turkey, Austria-Hungary, Germany and others states. At the beginning of the XXI century, the traditional for Russia problem of controlling the Black Sea straits have been compounded by ensuring the presence of the fleet in the Adriatic and Mediterranean seas, as well as the problem of controlling the routes for the transport of energy resources to the countries of Southern and South-Eastern Europe. It is known that the presence of strategic partners in the region determines the success of the implemented policy. For Russian politics in the Balkans, such countries as Bulgaria, Serbia, and Montenegro became the partners both in the XIX and early XX centuries. Moreover, both then and these days, the degree of effectiveness of international political interaction is determined by cultural, religious as well as economic and investment instruments. However, as political practice shows, they are not always crucial, since as the subjectivity of the Balkan countries increases, each of them sought to define a circle of their own priorities that did not always coincide with the ideas of Slavic "unity and brotherhood" under the patronage of the Russian state.

Despite the fact that Montenegro withdrew from the State Union with Serbia in 2006 and joined NATO in 2017, the country has always been an active subject of ethno-political processes in the Balkans. Despite attempts by Serbian patriotic circles to represent Montenegro as a "historic state of the Serbian people" and integration into Western structures as a "mafia anti-state for Serbia" [Раковић, 2017: 71], Montenegrin statehood has a steady historical tradition embodied in various forms of state administration - a theocratic and secular principality, monarchy, and finally the present parliamentary republic. Neither being part of the Byzantine Empire, nor the Serbian state, nor Venice (where, in fact, it was called "Monte Negro"), did not break the invincible spirit of the Montenegrin people. Despite the fact that since the late XV century much of present-day Montenegro was under the control of the Ottoman Empire, for a long time the center of the liberation movement remained in the city of Cetinje (now one of the capitals of the country) - the residence of Metropolitans and political leaders. During the XVIII-XIX centuries Montenegrin lords of the Petrovich-Negosha dynasty traditionally focused on political and economic support of Russia, which considered the territory as an outpost in the fight against the Ottoman Empire. At the end of the XVIII century, Montenegro was the first of the Southern Slavic countries to regain de facto independence. This was confirmed at the 1878 Berlin Congress, which, through the support of Russia, recognized its sovereignty at the international level. As a result of the First World War, despite the fact that Montenegro supported the Entente, it was annexed to Serbia and subsequently joined the unitary Kingdom of Yugoslavia. In 1946 it became one of the republics of the Federal Yugoslavia (SFRY).

The transformation of Montenegro into a popular tourist destination is closely linked to the Yugoslav model of socialism created by the charismatic leader J. Broz Tito. It effectively combined international tourism with the priorities of multi-vector foreign policy, thereby achieving certain 
economic and political benefits. Thus, in theconditions of the Cold War, Yugoslavia becomes the leader of the Non-Aligned Movement and a global player between Western democracies and the political regimes of the socialist camp. Interested in preventing the entry of Yugoslavia into the orbit of foreign policy influence of the USSR, the US political elite promoted comprehensive economic assistance to the Tito government to preserve his independent policy [Pavlov, Pashintseva, 2010]. Yugoslavia's investment tourism projects were firmly based on a liberalization policy of the mobility regime. By the 1960s, most foreigners arriving in Yugoslavia received a visa at the border. Montenegro's transformation into a popular tourist destination was facilitated by the grand "Southern Adriatic" tourism development plan, developed in 1962 in close collaboration with the United Nations Development Program with the involvement of the world's best experts [Touristic Masterplan, 2001]. With the construction of the 1965 Adriatic Highway and the construction of large hotel complexes, the Budva Riviera has become a place of attraction for both the western star bohemian and the representatives of the so-called "middle class", mostly from Austria, the United Kingdom, Italy, Germany, France, the Czech Republic and other countries.

In the early 1990s, Montenegro was drawn into the Yugoslav crisis, during which only Serbia and Montenegro maintained allegiance to the allied state. The development of the economy and tourism, as its component, faced a longstanding stagnation that lasted until almost 2003. Thus, in the late 1980s - early 1990s, the financial system of Yugoslavia, which was constantly fueled by international loans, collapsed. In the context of ethnic and religious conflicts, political instability associated with the formation of sovereign states in the former SFRY (Croatia, Slovenia, Bosnia and Herzegovina, Macedonia), the further development of foreign tourism was impossible. The decrease in the volume of inbound tourist flow was particularly noticeable from 1987 to 1993 . The number of tourist arrivals in this category decreased from 1.3 million to 76.6 thousand people [Ковачевић, 2018: 67].

The formation of a modern tourist infrastructure and the development of international tourism in the Federal Republic of Yugoslavia (the so-called "The Third Yugoslavia"), created in 1992 by Serbia and Montenegro, were impossible due to harsh international sanctions. They were imposed by the UN through the involvement of the Union State army in the Balkan Wars (1992-1996) and the Kosovo policy (1998-1999) that led to the 1999 bombing of NATO.

The division of powers in the Union State and economic contradictions exacerbated the differences between Serbia and Montenegro. Montenegro's tourism-dependent economy was more open to the outside world than the Serbian economy, and was more affected by conflict and sanctions [Tyagunenko, 2001: 43]. In such circumstances, the efforts of the ambitious Prime Minister M. Đukanović were aimed at accelerating reforms, overcoming the "outside wall" of economic sanctions, conducting privatization and attracting investments in the tourism sector. According to Montenegrin researcher B. Vukićević, despite the predominance of "anti-Western, pro-Russian and pro-Serbian positions" in the country, the resources for further isolation were "exhausted" [Vukićević, 2017: 114]. Under these circumstances, in 1997, M. Đukanović disassociated himself from the odious allied President S. Miloševićand became a pillar to fight his regime. With the victory of M. Đukanović in the presidential election on October 19, 1997, begins the resumption of bilateral relations with Moscow bypassing Belgrade. In particular, as early as 1998, Moscow, interested in using the Adriatic port infrastructure by oil and gas companies and penetrating the region of the Russian capital, in support of M. Đukanović, opened a Russian consulate in Podgorica [Sysoev, 1998: 28]. At the same time, M. Đukanović develops and deepens relations with EU countries and the USA, which allows to obtain political and financial support for the reforms.

Montenegro started to conduct its own monetary, fiscal, foreign trade and other policy, initiated its own central bank, introduced the German Mark (1999) as a means of payment, which was replaced by the euro in 2002 [Uvalić, ${ }^{2018}$ ]. Against the backdrop of the West's explicit support for the course pursued by M. Đukanović, such a policy created a nourishing basis for intensifying the internal political struggle between the supporters of independence (Liberal Alliance Party, Social Democratic Party) and the preservation of the Yugoslav Federation (Socialist People's Party) 
[Tyahunenko, 2001]. The Yugoslav leadership refused to accept the idea of the "loss" of Montenegro, and accordingly - the exit to the sea. With the introduction of Montenegro's twocurrency system, Serbia is establishing a serious trade blockade for its partner. The corresponding policy was fostered by "reverse nationalism", which in the International Crisis Group's report was called a "model of coercive self-determination" [Montenegro, 2000].

The aforementioned internal conflict was reasonably incited by the success of tourism sector in Croatia, which, despite the bloody war of independence, since mid-1990s had been using the opportunities of open political borders to attract tourists from Central and Eastern Europe. As early as 1998, 32.8 million overnight stays were recorded on the Croatian Adriatic [Ateljevic, Corak, 2006], which helped stabilize the country's economic and political system. Appropriate aspirations aimed at restoring foreign tourism were cultivated in Montenegrin society. They were promoted by President M. Đukanović himself, a professional economist in the field of tourism, who received a corresponding higher education at the University of Montenegro in Podgorica. He repeatedly invited Western and Russian tourists to visit the country. In a somewhat non-fiction form, the corresponding sentiment was echoed by Russian Balkanist $\mathrm{M}$. Bondarev, noting that even Montenegro's separation from Serbia in 2006 should be seen as a "triumph of the tourist mentality over common sense." In his opinion, this was reflected by a referendum on independence, in which the tourist Primorye voted for the exit while the Montenegrin "hinterland", inland regions of the country - against [Bondarev, 2017]. It should be noted that the independence of Montenegro was possible only because of a slight preponderance of the votes - 55.5\% supported the sovereignty of Montenegro, while $44.5 \%$ of those who participated in the referendum favored a common state with Serbia [Vukićević, 2017: 113].

The resumption of Montenegro's sovereignty in 2006 marked the final disintegration of Yugoslavia and continued the evolution of political processes in the country towards accession to the European Union and NATO, which was enshrined in the foreign policy doctrine [Vukićević, 2017: 115]. In post-socialist countries, tourism has played a traditionally important role in the provision of European integration, both in terms of the revitalization of old industrial areas and depressed rural areas, as well as in terms of democratic and national development. For the postYugoslavian Adriatic countries, tourism had to directly promote integration into European structures through the formation of employment, a shared space of values and European identity. This is evidenced by the Integrated Tourism DevelopmentMaster Plan in Croatia and Montenegro, developed in 2001 with the assistance of the Ministry of Economic Cooperation and Development of Germany, which was implemented within the framework of the Stability Pact for South Eastern Europe [Touristic Masterplan, 2001].

At the same time, it was noted that in the late 1990s and early 2000s Russia was "returning" to Montenegro. The resumption of diplomatic ties was underpinned by the economic and investment activity of Russia, whose economy was growing in the 2000s. The rapid penetration of Russian capital was facilitated by the proximity of Russian political and business elites to the local top. The most famous examples are the construction of a resort village by Moscow Governor Y. Luzhkov close to Sveti Stefan, and in 2005 the acquisition by Russian billionaire O. Deripaska of an aluminum plant in Podgorica, the largest industrial enterprise in the country, which at that time produced 51\% of export and 15\% of GDP [Bechev, 2018: 6].

Liberalization of economic policy, alongside the development of the shadow sector, contributed to the attraction of Russian investment in the hotel sector and residential construction. Simplified conditions for starting a business, taxation and real estate acquisition have caused a real construction and tourism boom. The entire territory of the country has been designated as a free trade and development area. The peak of investment activity occurs in 2008-2014 and is quite stable. Thus, during 2010-2014alone, the average annual volume of Russian investments amounted to \$ 1,100 mln. USD [Direct Investment, 2014], which is quite high per capita in Montenegro. Visafree travel, linguistic accessibility, friendly Montenegrins to Russians are quickly turning the country into a favorite vacation spot for the new Russian middle class. From 2006 to 2014, the number of Russians visiting Montenegro increased from 61,000 to almost 320,000 (Figure 1). In 
terms of inbound tourist flow, the share of Russia at that time reached 20-30\% (Fig. 2), which was the largest market for Montenegro. About 70,000 Russians have purchased relatively inexpensive real estate in Adriatic resorts [Conley, Melino, 2019: 4], accounting for 40\% of the country's resort real estate [Mamchitz, 2018]. Overall, the number of Russians who are permanent residents of Montenegro is estimated at 5-7,000 people [Strategic Analysis, 2016], while the Russian-speaking diaspora reaches 15,000 [Assessing Russia's, 2018: 4]. The proportion of Russians who reside permanently in Montenegro is particularly high at the seaside resort of Budva.

Figure 1

\section{Dynamics of the of inbound tourist flow structure in Montenegro and foreign exchange earnings from tourism}

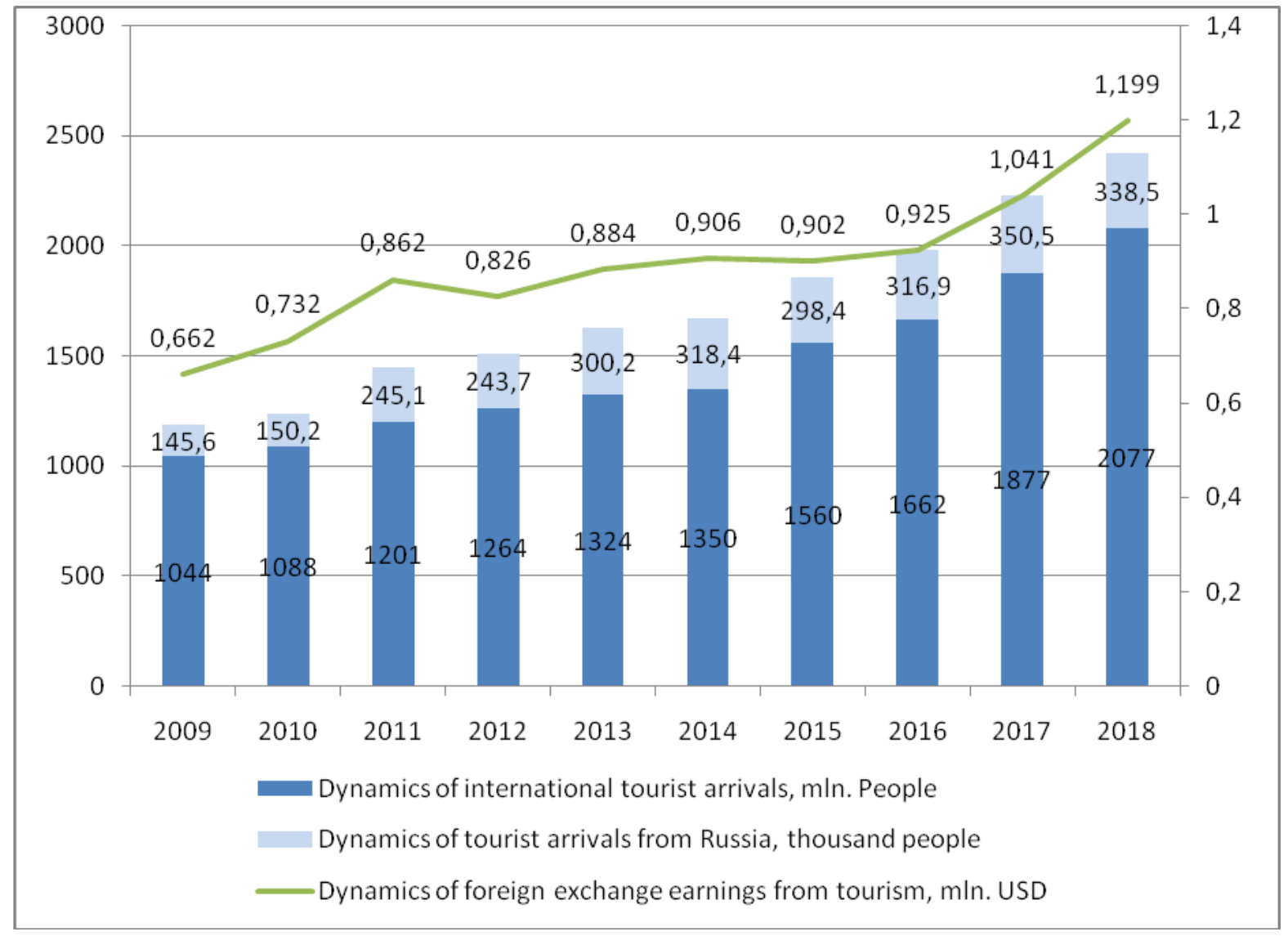

Source: author’s development based on materials [Monstat, 2009-2018] 
Figure 2 total nights spent (\%)

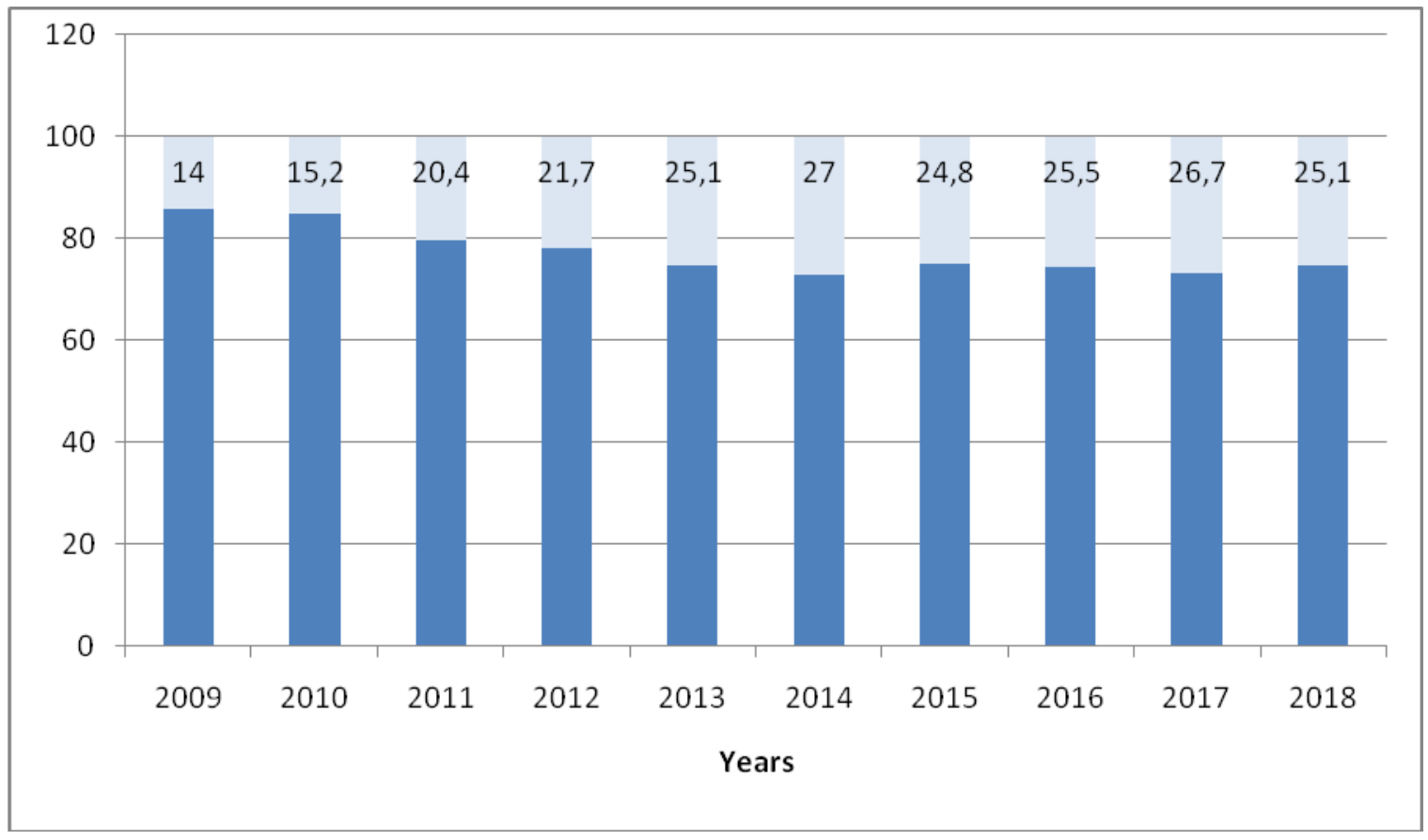

Source: author’s development based on materials [Monstat, 2009-2018]

The flow of Russian investment into Montenegro was also fueled by a ban on gambling in Russia in 2009. Instead, the Adriatic coast of Montenegro, where gambling was legalized with the accession of independence in 2006, has been a safe haven for Russian capital. Montenegro quickly acquired the image of a "gaming capital" that has established itself even at the level of popular culture. A prime example of this is the famous spy movie "Casino Royale" (2006), in which the main character, a British intelligence officer, J. Bond, takes part in a poker tournament at the Montenegrin five-star Splendid Hotel to complete his mission. At the same time, its plot reflects some of the negative connotations that have formed around the Balkans as a route for global drug trafficking and organized crime, as a whole. A. Violante's publication states that the origin of Russian money used to acquire Montenegrin real estate was dubious [Violante, 2017: 93]. Thus, one of the largest casinos in the Balkans - Casino Avala Budva - until recently belonged to T. Ismailov - the son of the former owner of the Cherkizovsky market in Moscow - whose assets were arrested in 2019 [Minak, 2019]. Overall, relations between Moscow and Podgorica remained so dense that by 2014, up to 32\% of Montenegrin enterprises were Russian-owned [Tomovic, 2016]. Most Russian assets in the country are real estate holdings, hotels, cafes, restaurants.

At the same time, Moscow's interests in the Balkans cross the limits of investment in coastal real estate and recreation on the Adriatic coast. Ever since the mid-2000s, the concept of the socalled Russian world (Russkiy Mir), as a trans-state community united on the basis of loyalty to Russia, Orthodoxy, Russian culture and language, has become one of the ideological imperatives of Russia's foreign policy. In the Western Balkans, this concept has been projected to counteract NATO's activities, viewed by Russia as an attempt to oust it from its traditional region of influence. The use of the ideas of Pan-Slavism, the appeal to a common Slavic culture, Orthodox Christianity and the historical role of Russia as a defender of the Slavic peoples has become widespread political 
practice. Signs of close relations with Russia were everywhere - the central pedestrian bridge in Podgorica was built as a gift from Moscow and named "Moscow Bridge", the monument to A. Pushkin was opened in front of the constitutional court, the monument to V. Vysotsky was built in the park in front of the Ministry of Defense. The Serbian Orthodox Church, which traditionally stands for the unity of the Montenegrin and Serbian peoples and supports anti-Western and antiNATO discourse, remains a special tool of influence of the Kremlin in Montenegro. In Montenegro, ethnic Serbs make up 30\% of the population, some of them identify themselves with their Slavic heritage, advocating the restoration of "Greater Serbia” and strengthening relations with Moscow [Conley, Melino, 2019: 3]. Overall, about 70\% of the country's residents are Orthodox. It should also be noted that Serbian tourists, as well as Russian tourists, are one of the largest market segments (Fig. 3).

Figure 3

\section{Geographic structure of inbound tourist flow to Montenegro, total nights spent (\%), 2018}

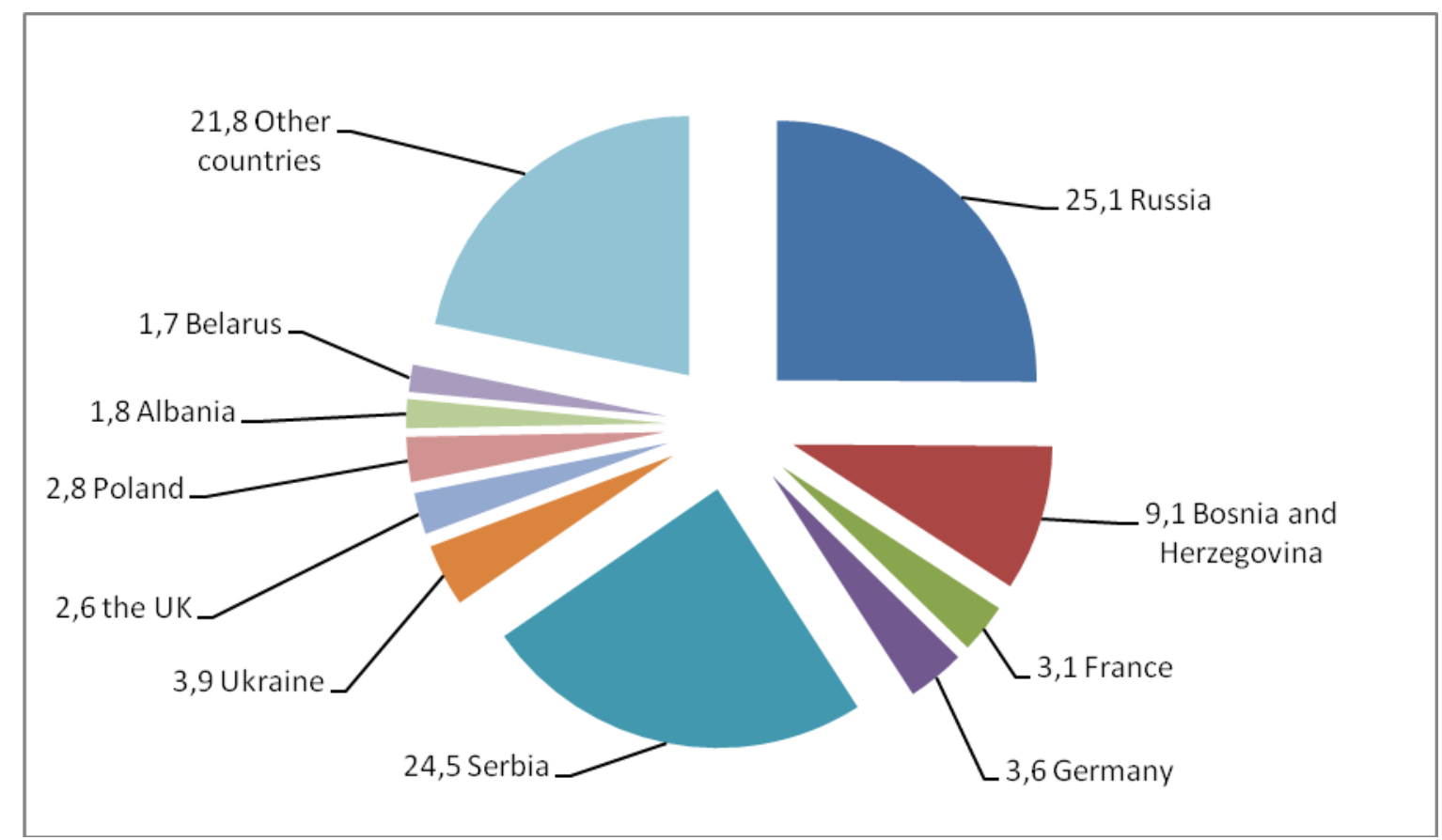

Source: author’s development based on materials [Monstat, 2009-2018]

Rates around Montenegro's geopolitical choice began to rise as it became integrated into NATO, in particular since joining the Membership Action Plan in 2009. Obviously, the foreign policy of M. Đukanović government for joining the Euro-Atlantic community, in the context of NATO membership of neighboring Croatia and Albania in 2009, went beyond the realistic paradigm of national security interests that Russia could not offer. Prospects of becoming a "Trojan horse" of Russia in the pro-Western camp, with further confrontation of relations, could have put an end to Montenegro's economy dependent on foreign tourism. For Russia, this meant losing the last part of the non-NATO Adriatic coast and undermining its influence in the region. Confidence in Montenegro as a reliable partner of Russia was questioned as a result of the nationalization of the assets of a Russian named A. Deripaska in the aluminum plant in 2012 without compensation to 
him for material damage. In 2013, an official Podgorica rejected proposals to discuss with the Russian delegation the conditions of stay of Russian ships in the deep-sea ports of Bar and Kotor, for which the Russian side seemed to have proposed several billion dollars [Vukićević, 2017: 126].

The point of no return in bilateral relations between Moscow and Podgorica was the occupation of Ukrainian Crimea by Russia and the use of hybrid war technologies, which accelerated Montenegro's determination to join NATO. The Montenegrin authorities remained a consistent supporter of the independence and territorial integrity of Ukraine [Frolov, 2016: 342343]. Montenegro's involvement in Western sanctions against Russia, applied in 2014 in response to aggression in Ukraine, caused an unprecedented annoyance with Russia. In the socio-political discourse of Montenegro, this was reflected in the spread of anti-Ukrainian and in the broad context of anti-NATO and pro-Russian rhetoric. X. Semanić's study on pro-Russian media in Montenegro states that a wide network of Russophile editions, prominent among which are the IN4S news portal (www.in4s.net) and the DAN daily, have become leaders of Russia-backed anti-Western attitude [Semanić, 2019]. Russian counter-sanctions in the form of an embargo on the supply of wine and meat products, as well as threatening statements by officials of the Kremlin, negatively affected the dynamics of the inbound tourist flow from Russia, which for the first time in many years decreased by $6.3 \%$ (Fig. 1 ).

Russia's support for nationalist pan-Slavic attitudes and parties [Bajrović, Garčević, and Kraemer, 2018: 6], as well as outspoken protests against the expansion of Euro-Atlantic institutions into the Balkans, has intensified NATO's resolve. In early 2016, Montenegro was finally invited to become a member of this organization. In such circumstances, the coming to power of the proRussian government could be an effective way out. Numerous calls for the preservation of cultural, historical and religious identity were embodied in a failed coup attempt. In October 2016, on the eve of the parliamentary elections to Skupština, Podgorica police arrested 19 people suspected of overthrowing the government and assassination of Prime Minister. Among the accused who were sentenced in Montenegro in May 2019 were probable Russian intelligence agents and representatives of Serbian political parties who tried to prevent NATO entry [Walker, 2019].

The escalation of political strife around Montenegro's geopolitical choice turned tourist flows from Russia into a component of foreign policy struggle that had already been successfully tested by the Kremlin during the crisis in Russian-Turkish relations in 2015-2016. On the eve of the 2017 tourist season, numerous news stories and articles about the dangers of Montenegro for the Russiansappeared on Russian TV channels [Crime, minefields and tetanus, 2017; Alliance at the ready, 2017], which spoke of "flourishing of crime", "anti-Russian attitudes", poor service, dirty and crowded beaches, etc. [Kravtsova, 2017]. On April 20Russian Foreign Ministry spokesman M. Zakharova claimed the "surge of anti-Russian hysteria" in Montenegro. According to M. Zakharova, against the background of "growing negative attitude to Russian business and our compatriots", the country does not exclude delays of Russians "for dubious reasons" [Ministry of Foreign Affairs of Russia warns, 2017]. In another comment, M. Zakharova advised "to think twice than to travel to this country" [Foreign Ministry Spokesperson, 2017]. The statement of Rosturism referred to "potential threats" and an "unfriendly environment for Russian tourists" in Montenegro. It is significant that the Kremlin propaganda company did not find support in the tourist business environment. Thus, in a statement by the spokesman of the Russian Union of Travel Industry I. Tyurina, it was said that Montenegro lacked anti-Russian attitudes and waiting of tourists from Russia [Tyurina, 2017]. In general, according to the data in Fig. 1. Moscow's efforts to use the tourist flow as a tool for foreign policy influence on Montenegro proved unsuccessful. This is due to the fact that a large part of Russian arrivals in Montenegro is formed by citizens who own property in the country and come independently, bypassing tourist companies. The sustainable dynamics of inbound tourism from Russia was also aided by Podgorica's decision to extend the visa-free travel of Russians in the country for up to 90 days during the holiday season [Montenegro allowed, 2019].

Despite the fact that the Kremlin failed to influence the reformatting of the tourist flow in Montenegro, stable dynamics of tourist arrivals from Russia, along with property owners, investors 
and the diaspora, have formed an influential Russian-speaking environment that using the paradigm of a transnational approach, has turned into a "transnational social space"(L. Priss, T. Feist). Its basic characteristics are the simultaneous inclusion in the social space of the country of exit (Russia) and the country of residence (Montenegro), interpenetration in the socio-economic, cultural and political life of both societies. In addition to the constant relocation of Russian tourists, which have become a key link in the interaction, transnational communication is supported through the circulation of migrants, remittances, trade, transport, telecommunications, values and meanings. This situation was exploited by Russia, which in order to strengthen its economic influence, deployed traditional tools of so-called "soft power". These include the presence in Russianlanguage media (Russkaya Gazeta, Russkiy Vestnik, Komsomolskaya Pravda in Montenegro, etc.), support of public organizations and political parties, use of influence of the Serbian Orthodox Church and others.

With the widespread rivalry of major powers in the region, significant ethnic-religious contradictions, mutual territorial claims, Montenegro's accession to NATO in June 2017 ensured the country's further sustainable development. At the same time, given more than three-hundred-year presence of Russia in the region, one can hardly imagine a scenario related to Moscow's departure from the region. The Turkish Stream gas transport system has significant prospects for expansion into the Western Balkans. Nowadays Montenegro has come close to EU integration and is formally the most successful Balkan candidate. For this reason, China, Russia, Turkey and other players seek to occupy their niche in the country's economy. Montenegro is also successfully benefiting from this, which in 2018 announced a citizenship for investment program, which allows obtaining a passport of a candidate country for EU membership when purchasing real estate. Against this background, it becomes clear that the future geography of tourist flows in the region is about to undergo changes as a result of the geopolitics of further EU enlargement. This can be the basis for political stability, access to EU financial resources, the open market, ensuring the competitiveness of the tourism industry and reformatting the geospatial structure of inbound tourism.

Conclusions and prospects for further research. In the context of globalization of world tourist flows, the increasing political and economic weight of tourism in ensuring international political interaction is becoming more and more evident. The politicization of the tourism process in dependent on the coastal tourism Montenegro has gained strong features at all stages of sociopolitical development. Starting with the emergence of mass holidays in Yugoslavia in the 1960s, tourism has always been linked to the foreign policy goals of the country, first serving as an instrument of escape from political isolation and later as the economic basis of the "third path" that Tito chose after the conflict with the Soviet Union. After the Yugoslav wars, tourism was recognized as a tool for economic recovery and became a factor in politically motivated rethinking of traditions, including relations with Serbia, Russia and the West. Tourism has become a factor in the electoral struggle in society and has influenced Montenegro's geopolitical direction. Despite considerable dependence on investment and tourism flows from Russia and related attempts to destabilize political situation in the country amid NATO accession, Montenegro has chosen a course of Euro-Atlantic integration. This suggests that culture and tourism were an important component of the new concept of sovereignty, where demonstrations of openness and a new European identity were the basis of Montenegro's geopolitical transformation - from the Balkans (with corresponding negative and conflicting connotations) to a country that has come closer to the EU.

\section{References}

1. Ateljevic I., Corak S. (2006). Croatia in the New Europe: Culture versus Conformity. In: Hall, D., Smith, M., Marciszweska, B. (eds) Tourism in the New Europe: The Challenges and Opportunities of EU Enlargement. London: Cabi International: 288-301. 
2. Bajrović R., Garčević V., Kraemer R. (2018). Hanging by a Thread: Russia's Strategy of Destabilization in Montenegro, Foreign Policy Research Institute, <https://www.fpri.org/wpcontent/uploads/2018/07/kraemer-rfp5.pdf>.

3. Bechev D. (2018). The 2016 Coup Attempt in Montenegro: Is Russia's Balkans Footprint Expanding? Foreign Policy Research Institute, <https:/www.fpri.org/article/2018/04/the2016-coup-attempt-in-montenegro-is-russias-balkans-footprint-expanding/> .

4. Boeckh K. (2014). Allies Are Forever (Until They Are No More): Yugoslavia's Multivectoral Foreign Policy During Titoism. In: Keil S., Stahl B. (eds) The Foreign Policies of Post-Yugoslav States. New Perspectives on South-East Europe. London: Palgrave Macmillan: 18-43.

5. Conley H. A., Melino M. (2019). Russian Malign Influence in Montenegro: The Weaponization and Exploitation of History, Religion, and Economics. Center for Strategic \& International Studies, <https:/www.csis.org/analysis/russian-malign-influence-montenegro>.

6. Djurovic G. (2012). Evropska Unija i Crna Gora - Politika Proširenja. Podgorica, Univerzitet Crne Gore, 569 str.

7. Džankić J. (2014). From Creeping to Sprinting: Foreign Policy of Montenegro. In: Keil S., Stahl B. (eds) The Foreign Policies of Post-Yugoslav States. New Perspectives on SouthEast Europe. London: Palgrave Macmillan: 173-197.

8. Grandits H., Taylor K. (Eds). (2010). Yugoslavia's Sunny Side: History of Tourism in Socialism (1958-1980s). Budapest: Central European University Press, 438 p.

9. Semanić H. (2019). Pro-Russian media in Montenegro after joining NATO. Prague Security Studies Institute, <https://www.balkancrossroads.com/pro-russian-media-in-montenegro>.

10. Tomovic D. (2016). Russians Dominate Foreign Ownership of Montenegrin Companies. Balkan Insight, August 18, <https://balkaninsight.com/2016/08/18/russians-own-every-thirdcompany-in-montenegro-report-08-17-2016/>.

11. Uvalić M. (2018). The Rise and Fall of Market Socialism in Yugoslavia. Project of the Dialogue of Civilizations Research Institute (DOC RI), Inequalities, Economic Models and the Russian October 1917 Revolution in Historical Perspective, University of Perugia, $<$ https://doc-research.org/2018/03/rise-fall-market-socialism-yugoslavia/>.

12. Violante A. (2017). Under Pressure: The Impact of Russian Tourism Investment in Montenegro. In: Hall D. (ed.) Tourism and Geopolitics: Issues and Concepts from Central and Eastern Europe. Wallingford: CABI: 87-96.

13. Vukićević B. (2017). Foreign Relations of Post-Independence Montenegro: A Change of Direction, Lithuanian Foreign Policy Review 36(1): 107-135.

14. Walker S. (2019). Alleged Russian spies sentenced to jail over Montenegro 'coup plot', The Guardian, 9 May.

15. Ковачевић 3. Г. (2018). Улога наутичког туризма у одрживом развоју Црне Горе: докторска дисертација. Ниш, 2018. Година.

16. Раковић $A$. (2017). Црна гора од сецесије до нато пакта: осврт на несналажење руске спољне политике (2006-2017), Наџионални Интерес 1: 69-86.

17. Assessing Russia's Economic Footprint in Montenegro (2018). Center for the Study of Democracy, Policy Brief: 73, January 2, <file://C:/Users/user/Downloads/CSD_Policy_Brief_73_Montenegro.pdf>.

18. Foreign Ministry Spokesperson Maria Zakharova's answers to media questions on Russia's relations with Montenegro (2017). The Ministry of Foreign Affairs of the Russian, $<$ http://www.mid.ru/ru/foreign_policy/news/-

/asset_publisher/cKNonkJE02Bw/content/id/2769225?p_p_id=101_INSTANCE_cKNonkJE0 2Bw\&_101_INSTANCE_cKNonkJE02Bw_languageId=en_GB $>$.

19. Monstat: Statistical Office of Montenegro. Tourism, 2006-2019, $<$ https://www.monstat.org/eng/page.php?id=43\&pageid=43>.

20. Montenegro: In the Shadow of the Volcano (2000), International Crisis Group (ICG), Balkans Report 89, <https://www.refworld.org/docid/3ae6a6db14.html>. 
21. Strategic Analysis: Russian Business Activity in Montenegro: Abstract (2016). RWR Advisory Group, <https://www.rwradvisory.com/russian-activity-in-montenegro-abstract>.

22. Touristic Masterplan for Montenegro: Integrated Overall Regional Approach to Reorganizing and Developing the Tourist Industry in Croatia and Montenegro (2001). Visit Montenegro, $<$ https://www.visit-montenegro.com/downloads/ministryoftourism/1-MASTER-

PLAN/DEG\%20EN\%20ExecSumm.pdf>.

23. WTTC (2019). Montenegro 2019 Annual Research: Key Highlights. WTTC, $<$ https://www.wttc.org/-/media/files/reports/economic-impact-research/countries2019/montenegro2019.pdf >.

24. Бондарев Н. (2017). Конец Черногории. О «революционном» воздействии туризма на государственную политику [The end of Montenegro: On the revolutionary impact of tourism on public policy], Century: Information and analytical publication of the historical perspective fund, 30 May, <http://www.stoletie.ru/zarubejie/konec_chernogorii_805.htm>.

25. Кравиова И. (2017). Туроператорам настойчиво предлагают не отправлять россиян в Черногорию. Почему? [Tour operators are urged not to send Russians to Montenegro. Why?]. Meduza [online edition], 4 May, $<$ https://meduza.io/feature/2017/05/04/turoperatoram-nastoychivo-predlagayut-ne-otpravlyatrossiyan-v-chernogoriyu-pochemu>.

26. Мамчии P. (2018). Российские инвесторы теряют Черногорию [Russian investors lose Montenegro], Invest Foresight: Business Magazine, 27 April, <https://www.if24.ru/kak-tsiframenyaet-obshhestvo-i-cheloveka/>.

27. Минак, K. (2019). В Черногории арестовали казино сына Тельмана Исмаилова [In Montenegro, the casino of the son of Telman Ismailov was arrested], Forbes, 24 June, $<$ https://www.forbes.ru/biznes/378491-v-chernogorii-arestovali-kazino-syna-telmanaismailova>.

28. Павлов В. С., Пашинщева E. О. (2010). Югославия в сфере геополитических интересов США в 60-х - начале 70-х гг. XX века [Yugoslavia in the Geopolitical Strategy of the USA in 1960s - early 1970s], Vestnik of Lobachevsky State University of Nizhni Novgorod 4 (1): 187-193

29. Слюсаренко, О. (2012). Україна - Чорногорія: соціально-економічне співробітництво: Монографія [Ukraine - Montenegro: Socio-Economic Cooperation]. Kyiv: Lybid,152 p.

30. Сысоев Г. (1998). Балканская битва за Москву [The Balkan battle for Moscow], Коммерсант Власть 21, <https://www.kommersant.ru/doc/14444>.

31. Тюрина, И. (2017). РСТ: россияне в Черногории не заметили антироссийских настроений, там ждут наших туристов [RUT: Russians in Montenegro did not notice antiRussian sentiments, they are waiting for our tourists there], Tourism Interfax, 20 April, $<$ https://tourism.interfax.ru/ru/news/articles/40630/>.

32. Тягуненко, Л. В. (2001). Союзная республика Югославия на рубеже XXI века. Природа югославского кризиса [The Federal Republic of Yugoslavia at the turn of the 21st century. The nature of the Yugoslav crisis], Modern and Current History Journal 3: 28-45.

33. Фролов, М. О. (2016). Українсько-чорногорські відносини: десятиріччя здобутків і подолання проблемних питань (2006-2016 pp.) [Frolov M. O. Ukrainian-Montenegrian relations: Decade of gains and overcoming of problematic issues (2006-2016)], Науковi праці історичного факультету Запорізького національного університету 46: 316-354.

34. Альянс наготове: Черногория в одном шаге от вступления в НАТО (2017). [Alliance at the ready: Montenegro is one step away from joining NATO], TV Russia1, 28 March, $<$ http://www.vesti.ru/doc.html?id=287130>.

35. Криминал, минные поля и столбняк: почему Черногория становится опасной для туристов (2017). [Crime, minefields and tetanus: why Montenegro is becoming dangerous for tourists], TV Zvezda, 25 March, <https://tvzvezda.ru/news/vstrane_i_mire/content/201703251100-mpeq.htm>. 
36. МИД РФ предупреждает о «антироссийской истерии» в Черногории (2017). [Ministry of Foreign Affairs of Russia warns of "anti-Russian hysteria" in Montenegro], Interfax, $<$ https://www.interfax.ru/russia/559276>.

37. Прямые инвестиции из Российской Федерации за рубеж по инструментам и странампартнерам в 2010-2014 годах (2014). [Direct investments from the Russian Federation abroad on instruments and partner countries in 2010-2014]. Central Bank of the Russian Federation, <http://cbr.ru/statistics/print.aspx?file=credit_statistics/dirinv_out_country.htm\&pid=svs\&sid=ITM_58823>.

38. Черногория разрешила подольше гостить без виз в стране для российских граждан (2019). [Montenegro allowed longer visits without visas in the country to Russian citizens], Regnum. <https://regnum.ru/news/society/2597105.html>. 